\title{
CORRELATION BETWEEN PLANT DIVERSITY AND THE PHYSICOCHEMICAL PROPERTIES OF SOIL MICROBES
}

\author{
SUN, Y. ${ }^{1}-$ SHI, Y. $.^{1,2}-$ TANG, Y. $.^{1,2}-$ TIAN, J. ${ }^{1,2}-$ WU, X..$^{*}$ \\ ${ }^{1}$ College of Pharmacy and Biological Engineering, Chengdu University, Chengdu 610106, \\ China \\ ${ }^{2}$ Key Laboratory of Coarse Cereal Processing Ministry of Agriculture, Chengdu University, \\ Chengdu 610106, China \\ *Corresponding author \\ e-mail:2206681513@qq.com
}

(Received 27 $7^{\text {th }}$ Sep 2018; accepted $16^{\text {th }}$ Jul 2019)

\begin{abstract}
OBJECTIVE: To study the correlation between plant diversity and the physicochemical properties of soil microbes. METHODS: The determination of the chemical properties of farmland soil in the research area can be achieved by potentiometer method, automatic analyzer method, molybdenumantimony anti-colorimetric method and gas chamber method. Based on the determination results, the relationship between plant diversity and soil microbial physical and chemical properties in the national nature reserve in rocky desertification area can be analyzed. RESULTS: The physical and chemical properties of soil in different grades of rocky desertification were significantly different. With the increase of rocky desertification, soil physical and chemical properties showed a response process from degradation to improvement. Soil organic matter, nitrogen, capillary water holding capacity, bulk density and porosity were significantly correlated with plant diversity, which played an important role in improving soil physical and chemical properties and promoting the restoration of plant diversity. Factor analysis showed that plant diversity at different levels in national nature reserves had different correlation with soil physical and chemical factors at different levels. The ratio between the significant correlation factors and the number of plants showed that the diversity of trees was greater than that of shrubs, and the diversity of shrubs was greater than that of herbaceous plants. Tree plant diversity factor plays a leading role. CONCLUSION: With the proposed method the physicochemical properties of soil microbes can be effectively studied.
\end{abstract}

Keywords: plant diversity, soil, microbes, physical and chemical properties, rocky desertification, the related factors

\section{Introduction}

Rocky desertification refers to the unreasonable social and economic activities of human beings in a fragile ecological environment, resulting in contradictions between people and land, vegetation destruction, soil erosion, gradual exposure of rocks, declining or even loss of land productivity, and presenting an evolutionary process or result similar to a desertified landscape (Steinauer and Tilman, 2016). The povertystricken population in the southwestern part of China is relatively concentrated, and the contradiction between people and land is very prominent (Bazerman et al., 2017; Jiang et al., 2017; Sun et al., 2016). Once the vegetation on the slope is destroyed, the soil erosion of the farmland is intensified, resulting in the loss of all the thin soil layers and serious rocky desertification, and the water and nutrient storage capacity is rapidly reduced. Rocky desertification has become a major ecological problem that restricts regional economic and social development in southwest China (He and Tang, 2016). Rock desertification governance has become an important part of Chinese social and economic construction. However, the current research on rock desertification restoration 
ecology lags far behind the practice of rock desertification control (Thakur and Milcu, 2015). The restoration and reconstruction of rocky desert ecosystems seriously lacks the scientific support of relevant theoretical research, resulting in insignificant results of rocky desertification control. There are a series of problems such as simple structure, poor stability and weak resistance, which are difficult to maintain the governance results after the treatment of rocky desertification (Nyemb et al., 2018; Sudhan et al., 2018).

Species diversity is a manifestation of biodiversity at the species level, which can characterize the structural complexity of a biome, reflecting the structure type, organization level, development stage, stability level and habitat level of the community. It is an important organic component of biodiversity and is a research hotspot in the field of ecology (Zhalnina and Dias, 2015). At the same time, the restoration of species diversity is one of the most important features in the process of vegetation restoration. The farmland soil is an important part of the terrestrial ecosystem, and it is the carrier of many ecological processes of the ecosystem. It is an indispensable research content in the process of plant community renewal and succession. Through the study of the changes of soil physicochemical properties in the process of ecosystem succession under specific environmental conditions ( $\mathrm{Li}$ and Zhang, 2015a), it will help to understand the interaction and mechanism of aboveground and underground interactions in the evolution of ecosystems, and then provide a scientific basis for the process of artificially regulating forest regeneration succession (Lloret and Mattana, 2015). But so far, although the research on the single ecological process of ecosystem is deep, the research on the correlation between ecosystem plant diversity and soil physicochemical properties is lack of in-depth research, and there is no research on the response of its spatial and temporal differentiation and its succession to rocky desertification (Camara et al., 2018; Shen et al., 2017; Xiao et al., 2018). After artificial regeneration and succession of rocky desertification environment, there is still a lack of research on what are the characteristics and trends of plant diversity and soil physicochemical properties, how the succession of artificial vegetation affects the evolution of underground farmland soil, and what kind of forest vegetation can be constructed to improve the soil properties of farmland in this area (Weidner and Koller, 2015). Therefore, this study in 2017, and national nature reserve in rocky desertification area as the research object, research on plant diversity and soil physical and chemical properties and their relations, and explore the plant diversity and changes of soil physical and chemical properties and their reaction mechanism, in order to provide theoretical support for forest ecological protection and ecosystem restoration and reconstruction of rocky desertification in Guizhou, even in Southwest China.

\section{Material and methods}

\section{Overview of the study area}

In this study, three typical rocky desertification areas and one national nature reserve as research areas are selected, which represents the different climates, topography, vegetation zoning and farmland soil conditions in a rocky desertification area.

The research area 1 is mainly located in the plateau mountainous areas of the Guizhou Province. The terrain is undulating and the elevation is $1400-1742 \mathrm{~m}$. The annual average rainfall of the basin is $863 \mathrm{~mm}$, the annual maximum precipitation is $995 \mathrm{~mm}$, and the annual minimum precipitation is $618 \mathrm{~mm}$. Rainfall is mainly distributed from July to September, accounting for $52 \%$ of the total annual rainfall. The 
rock is dominated by carbonate-like limestone, with some Jurassic purple sand shale and shale distribution (Mellado-Vázquez and Lange, 2016). The farmland soil is dominated by yellow loam and purple sand. The vegetation is a subtropical evergreen deciduous coniferous and broad-leaved mixed forest, and the native vegetation is basically destroyed. It is now dominated by secondary forests (Kolton and Graber, 2016). The wild vegetation is vines, thorns, shrubs, which are mainly Pyracantha angustifolia, Rosa roxbunghii, Pyracantha fortuneana, Clematis florida and sporadic distribution of Cyclobalanopsis glauca, Pinus massoniana, Betula luminifera.

Study Area 2 is located in the township of the Guizhou Province, $12 \mathrm{~km}$ away from the county seat. The landform type is a typical plateau basin. The slope of the central part of the dam is slow, and the elevation in the basin is 1271-1451 m. The annual average rainfall of the basin is $1215 \mathrm{~mm}$, and the rainfall is mainly distributed from April to August, accounting for $75 \%$ of the total annual rainfall. The rocks are mostly Triassic dolomite, argillaceous dolomite and shale. The farmland soil is dominated by yellow soil and yellow lime soil. Natural vegetation accounts for a small proportion of the area. The common arbor is mainly cedar (Vej and Lamentowicz, 2015), and the shrub layer is mostly typical limestone thorn bush, with Viburnum chinshanense, Pyracantha fortuneana, Rubus corchorifolius, and Rhamnus hemsleyana, etc., common species of the herbaceous layer are Imperata cylindrica, Miscanthus floridulu, Miscanthus sinensis, Arthraxon hispidus, Clematis florida, etc.

The study area 3 is located on the banks of the canyon of the Guizhou Province. The landform types are divided into two parts: the plateau area and the canyon area. There are mainly five types of landforms in the basin, and four types are karst landforms with an altitude of $450-1450 \mathrm{~m}$. The difference is $1000 \mathrm{~m}$. The annual average rainfall of the basin is $1100 \mathrm{~mm}$, and the rainfall is mainly distributed from May to October, accounting for $83 \%$ of the total annual rainfall. The rocks are mostly Triassic dolomite, argillaceous dolomite and shale (Zhang and Johnston, 2017). The farmland soil is dominated by yellow soil and yellow lime soil. The vegetation is a subtropical evergreen deciduous coniferous and broad-leaved mixed forest, and the primary vegetation is basically destroyed. It is now dominated by secondary forests. The wild vegetation is vines, thorns, shrubs, which are mainly Pyracantha angustifolia, Rosa roxbunghii, Pyracantha fortuneana, Clematis florida and sporadic distribution of Cyclobalanopsis glauca, Pinus massoniana, Betula luminifera

Study area 4 is carried out in a certain test area of the Guizhou Province. The test area is located in a national nature reserve in the Guizhou Province. Except for a small amount of sand shale leakage, it is mainly composed of pure dolomite and limestone with exposed peak clusters, peak forests and Canyon landforms, as well as limestone soil and evergreen deciduous broad-leaved mixed forest (Zhou and Zhang, 2016). The test area belongs to the mid-subtropical mountain monsoon humid climate, with an average annual temperature of $15.3{ }^{\circ} \mathrm{C}$, an average temperature of $5.2{ }^{\circ} \mathrm{C}$ in January, an average temperature of $23.5{ }^{\circ} \mathrm{C}$ in July, a growth period of $237 \mathrm{~d}$, annual rainfall of $1752.5 \mathrm{~mm}$, and concentrated distribution from April to October. The annual average relative humidity is $83 \%$, and there are 827 species of 408 families and 408 genera of vascular plants, such as calcicole (Manglietia calcarea, Rhammus calcicolus, Cinnamomum calcarea, Phoebe calcarea, Stachyurus lipoensis, Camellia rubimuricata, Indosasa lipoensis, Acer liponsis, Hoya lipoensis and Tengia scopulorum), and national key protected plants (Handeliodendron bodimieri, Amentotaxus argotaenia, 
Euryocrymbus cavalerier, Emmenopterys henryi, Tetrathyrium subcordatum and Calocedrus macrolepis). Figure 1 shows the map of zserve in zovince.

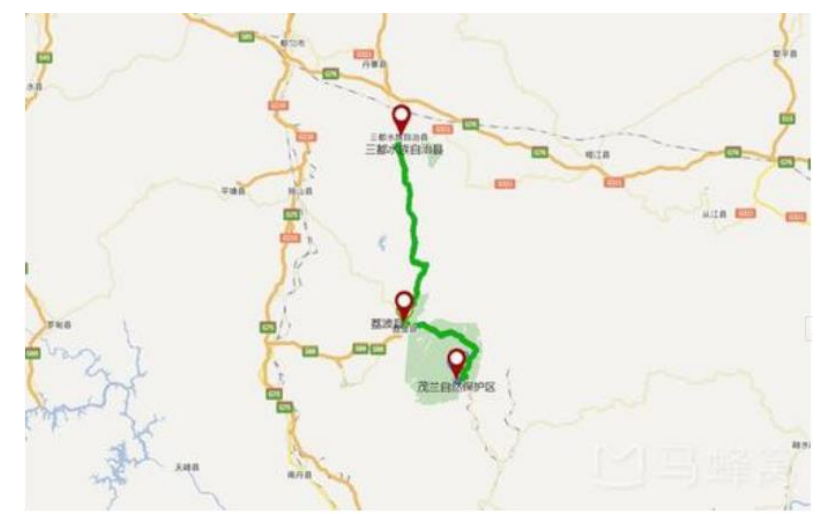

Figure 1. Map of Maolan Nature Reserve, Guizhou Province

\section{Research methods}

Sample setting

Based on the detailed investigation of the rocky desertification research area, five typical stages in the process of rock desertification succession are selected as the research objects, namely rockless desertification, potential rocky desertification, mild rocky desertification, moderate rocky desertification and intensity rocky desertification. The classification of rocky desertification is based on the results of expert research (Sun and Müllerschärer, 2015). For the five rocky desertification eco-environments, 45 research samples are set up in each of the four research areas, each of which has an area of $20 \mathrm{~m} \times 20 \mathrm{~m}$. The details of the sample are shown in Table 1. To analyze the physical and chemical properties of soil microorganisms, the basic information of the soil samples for the experiment should be clearly known. The basic information of the sample soil is given in Table 1 .

In a national nature reserve, survey lines are set along the core area, buffer zone and test area, and the outer edge of the protected area. The number of forest survey plots established in different functional areas (interference levels) series are 12, 17, 9 and 3, respectively. One. The survey plot area is $20 \mathrm{~m} \times 20 \mathrm{~m}$, and the altitude, slope direction, slope position, slope, parent rock and farmland soil type are recorded (Baćmaga and Wyszkowska, 2016). Each plot is investigated for three layers of plants: arbor, shrub and grass. Diameter at breath height (abbreviated as DBH, the same below) $\geq 5 \mathrm{~cm}$ is classified as arbor and DBH $<5 \mathrm{~cm}$ is classified as shrub. The sample area is $10 \mathrm{~m} \times$ $10 \mathrm{~m}$ in the arbor layer, $10 \mathrm{~m} \times 10 \mathrm{~m}$ in the shrub layer, and $10 \mathrm{~m} \times 10 \mathrm{~m}$ in the herb layer and the litter layer. The shrub layer, herb layer and litter layer are respectively set up three, representing that the development of each layer of plants or forest litter quantity is better, general, poor type. Among the vegetation survey indicators, the plants in arbor layer include the species name, $\mathrm{DBH}$, tree height, number of plants, height under the branches, crown width and coverage, the plants in shrub layer include species name, ground diameter, height, number of plants and coverage, and plants in herbaceous layer include species, number of plants, height and coverage (Markowicz and Woźniak, 2015). The field sample is completed once in the first half of August of the survey year 2017. 
Table 1. Basic information of the study area and sample square setting

\begin{tabular}{|c|c|c|c|c|c|c|c|}
\hline $\begin{array}{l}\text { Experiment } \\
\text { sites }\end{array}$ & Location & Altitude (m) & Landform & Soil type & $\begin{array}{c}\text { Degree of } \\
\text { rocky } \\
\text { desertification }\end{array}$ & $\begin{array}{c}\text { Percentage of } \\
\text { exposed rock } \\
(\%)\end{array}$ & $\begin{array}{c}\text { Sum (serial } \\
\text { number) of } \\
\text { square }\end{array}$ \\
\hline 1 & $\begin{array}{l}\text { Saraci, Bijie City, } \\
\text { Guizhou Province }\end{array}$ & $1400-1742$ & $\begin{array}{l}\text { Karst plateau } \\
\text { mountains }\end{array}$ & $\begin{array}{l}\text { Yellow soil, } \\
\text { yellow lime } \\
\text { soil }\end{array}$ & $\begin{array}{l}\text { Intensive } \\
\text { Moderate } \\
\text { Mild } \\
\text { Potential } \\
\text { Nothing }\end{array}$ & $\begin{array}{c}30-35 \\
20-29 \\
0-5 \\
0-5 \\
0\end{array}$ & $\begin{array}{c}1(1-3) \\
1(4-6) \\
1(7-9) \\
1(10-12) \\
1(13-15)\end{array}$ \\
\hline 2 & $\begin{array}{l}\text { Hongfeng Lake in } \\
\text { Qingzhen, Guizhou } \\
\text { Province }\end{array}$ & $1271-1451$ & $\begin{array}{l}\text { Karst plateau } \\
\text { basin }\end{array}$ & $\begin{array}{l}\text { Yellow soil, } \\
\text { yellow lime } \\
\text { soil }\end{array}$ & $\begin{array}{l}\text { Intensive } \\
\text { Moderate } \\
\text { Mild } \\
\text { Potential } \\
\text { Nothing }\end{array}$ & $\begin{array}{c}30-35 \\
20-29 \\
0-5 \\
0-5 \\
0\end{array}$ & $\begin{array}{c}2(1-3) \\
2(4-6) \\
2(7-9) \\
2(10-12) \\
2(13-15)\end{array}$ \\
\hline 3 & Anshun, Guizhou & $450-1450$ & $\begin{array}{c}\text { Karst plateau } \\
\text { canyon }\end{array}$ & $\begin{array}{l}\text { Yellow soil, } \\
\text { yellow lime } \\
\text { soil }\end{array}$ & $\begin{array}{l}\text { Intensive } \\
\text { Moderate } \\
\text { Mild } \\
\text { Potential } \\
\text { Nothing }\end{array}$ & $\begin{array}{c}30-35 \\
20-29 \\
0-5 \\
0-5 \\
0\end{array}$ & $\begin{array}{c}3(1-3) \\
3(4-6) \\
3(7-9) \\
3(10-12) \\
3(13-15)\end{array}$ \\
\hline 4 & Maolan, Guizhou & $430-1078$ & $\begin{array}{l}\text { Karst plateau } \\
\text { nature reserve }\end{array}$ & $\begin{array}{c}\text { Yellow soil, } \\
\text { yellow lime } \\
\text { soil }\end{array}$ & $\begin{array}{l}\text { Intensive } \\
\text { Moderate } \\
\text { Mild } \\
\text { Potential } \\
\text { Nothing }\end{array}$ & $\begin{array}{c}30-35 \\
20-29 \\
0-5 \\
0-5 \\
0\end{array}$ & $\begin{array}{c}3(1-3) \\
3(4-6) \\
3(7-9) \\
3(10-12) \\
3(13-15)\end{array}$ \\
\hline
\end{tabular}

\section{Analysis of plant diversity}

In October 2017, the density $\left(\operatorname{strain} / \mathrm{m}^{2}\right)$, average crown width $\left(\mathrm{m}^{2} / \mathrm{strain}\right)$ and coverage (\%, That is, the proportion of the total area of the crown and the total area of all the trees), average DBH (cm/strain), average height $(\mathrm{m} / \mathrm{strain})$, and aboveground biomass are used to calculate community diversity (Yan and Zhang, 2016). The diversity measure indicators are:

Richness:

$$
\mathrm{R}=\mathrm{S}
$$

Shannon-Wiener index of diversity:

$$
H=-\sum_{i=1}^{s}(P i \ln P i)
$$

Uniformity index:

$$
E=H / \ln S
$$


Simpson dominance index, $D=\sum_{i=1}^{s} P i^{2}, \mathrm{~S}$ represents the total number of species in the community, $P i$ is the proportion of the number of individuals of species $i$ to the total number of individuals in the community, i.e. $P i=n_{i} / N, n_{i}$ is the number of individuals of species $\mathrm{i}, \mathrm{N}$ is the total number of individuals observed.

\section{Collection of farmland soil samples and analysis of their physicochemical properties}

(1) Collection of farmland soil samples in the rocky desertification research area

In the center of each plot, three sampling points are selected in a serpentine manner, and the spacing between the points is within $5 \mathrm{~m}$. In October 2017, samples are taken 3 times at each point with a cutting ring $(0-15 \mathrm{~cm})$ and uniformly mixed to form a soil sample to be tested ( $\mathrm{Li}$ and Zhang, 2015b). In a rocky desertification area, the farmland soil is very thin, and some of it is only about $15 \mathrm{~cm}$. Therefore, it is used as a research object in the $0-15 \mathrm{~cm}$ farmland soil layer.

\section{(2) Determination of soil physical properties in farmland}

The volumetric weight, field water holding capacity, natural water content and capillary water holding capacity are determined by cutting ring method; total porosity is calculated by $p_{t}=93.947-32.995 \times b, \mathrm{~b}$ is bulk density, $p_{t}$ is total porosity; capillary porosity is determined by cutting ring method; $p_{o}=p_{t}-p_{c}$ is used to calculate noncapillary porosity, $p_{o}$ is non-capillary porosity, $p_{c}$ is capillary porosity; permeability characteristics are determined by double-ring permeation.

\section{(3) Determination of soil chemical properties in the study area}

The $\mathrm{pH}$ value is determined by the potentiometer method using a water-to-earth ratio of 2.5:1. The organic matter is determined by oxidation of potassium dichromate with sulfuric acid to volumetric method; the whole nitrogen is potassium borate with copper sulfate as the selenium powder, and the automatic analyzer is determined by nitrogen analyzer. Hydrolyzed nitrogen is determined by alkali diffusion method; total phosphorus is determined by sulfuric acid for perchloric acid digestion and molybdenum anti-colorimetric method; effective phosphorus is determined by sodium bicarbonate extraction for molybdenum antimony colorimetric method; Hydrofluoric acid is determined by perchloric acid decoction flame photometer; available potassium is determined by flame photometric method using neutral ammonium acetate extraction (Ma and Baskin, 2017); farmland soil respiration is determined by gas chamber method.

(4) Collection and analysis of farmland soil samples in a national nature reserve

Combined with the plot survey, farmland soil sampling points are set up in each plot according to the three types of good, general and poor under-forest vegetation development. After removing the litchi cover layer of the sampling point, only the layer A of the farmland soil, or the layer A and the layer B, are sampled separately. The total weight of the soil sample of each layer is about $1 \mathrm{~kg}$, and the soil sample is brought back to the laboratory under natural conditions. After air drying, the roots and gravel visible to the naked eye and the roots and coarse sand with a $1 \mathrm{~mm}$ mesh sieve are 
removed, and the main chemical indicators of the farmland soil after grinding are determined (Baleshta and Simard, 2015). At the same time, according to the soil profile of farmland, the ring knife and sealant seal are extracted and brought back to the laboratory to analyze the main physical indexes of farmland soil, record the rock exposure rate of the sample plot, soil thickness, color, texture, root volume and amount of gravel.

\section{Data processing and analysis}

Drawing is performed using Excel software, and statistical analysis of variance analysis, t-test, multiple comparison (Duncan test), correlation analysis and principal component analysis are performed using SPSS 16.0 software (Økland and Nordbakken, 2016).

Calculation of plant diversity index:

Important value of arbor layer species:

$$
I V=\frac{R D+R F+R T}{300}
$$

In Equation 4, RD is the relative dominance, RF is the relative frequency, and RT is the relative density.

Species richness - Margalef index:

$$
\operatorname{Mar}=\frac{S-1}{\ln N}
$$

Ecological dominance - Simpson index:

$$
\operatorname{Sim}=1-\sum_{s=1}^{s} \frac{N_{i}\left(N_{i}-1\right)}{N(N-1)}
$$

Information diversity - Shannon-Wiener index of:

$$
\text { Sha }=-\sum_{s=1}^{s} P_{i} \ln \mathrm{P}_{i}
$$

Uniformity index - Pielon index:

$$
\text { Pie }=\frac{H}{\ln S}
$$

In the above equations, $\mathrm{S}$ represents the number of species, and $N_{i}$ and $\mathrm{N}$ represent the number of species and all species, respectively

$$
P_{i}=N_{i} / N
$$




\section{Results \\ Vegetation species composition and plant diversity of different grades of rocky desertification environment}

\section{Species composition}

Vegetation species survey results show that the vegetation composition of rocky desertification environment is simple, and with the deepening of rocky desertification, the vegetation species composition shows a decreasing trend, and the Huajiang River with the highest degree of rocky desertification (Research Area 3) has the simplest vegetation community. There are only 8 families, 12 genera and 13 species in the layer, and there are only 10 families, 13 genera and 13 species in the wood layer. The richness of vegetation species in a rocky desertification area is also very low. Most species are 1 family, 1 genera and 1 species, and only 1 has Compositae, Rosaceae, and Gramineae. The families of Caprifoliaceae, Moraceae, Euphorbiaceae, and Rhamnaceae are mostly of many life types, indicating that these groups have better adaptation to the rocky desertification environment.

Among them, the Rosaceae species have more genus, species and life-type distribution in the potential and mild rocky desertification environment, but the distribution in the rocky desertification environment drops sharply, showing the adaptability of same species for different grades of rocky desertification environment has significant differences. The important value study of species also shows that there are significant differences between the established and dominant species of plant communities in different grades of rocky desertification. In the potential-light rocky desertification environment, species such as Saccharum arundinaceum, Robinia pseudoacacia, Ligustrum lucidum, and Artemisia dubia are dominant or established species of plant communities; In the light-moderate rocky desertification environment, the dominant or established species of plant communities are Miscanthus floridulus, Setaria viridis, Pteris multifida, Leptorhabdos parviflora, Viburnum propinquum, Itea yunnanensis and other species; in the moderate-intensity rocky desertification environment, the dominant species or plant species of the plant community are foxtail, Arthraxon hispidus, Broussonetia papyrifera, Lonicera japonica, Ampelocalamus calcareous, etc. Table 2 shows the adaptability differences of rocky desertification environments at different levels.

\section{Plant diversity}

The plant diversity of four research areas was detected by Hashi Amtax NA8000 ammonia nitrogen automatic monitor. The following results were obtained. The results show that the four indices of plant diversity in rocky desertification environment are low (Table 3), indicating that the rocky desertification plant ecosystem has been destroyed, and the restoration succession is at a lower stage. The results also show that the four indexes of plant diversity in different grades of rocky desertification environment are significantly different: (1) The uniformity index of rockless desertification environment is significantly larger than the potential rocky desertification, and the potential rocky desertification is significantly larger than the mild, moderate and intensity rock desertification. (2) The environmental richness index of rockless desertification and mild rocky desertification is significantly larger than that of potential rocky desertification. (3) The environmental diversity index of rockless 
desertification, potential rocky desertification and mild rocky desertification is significantly smaller than that of intensity rock desertification. There is no significant difference between rockless desertification, potential rocky desertification and mild rocky desertification. (4) The dominance index of potential rocky desertification environmental is significantly larger than other rocky desertification environments. It can be seen that among the four indices of plant diversity of rocky desertification environment, only the uniformity index change is significantly coupled with the succession of rocky desertification grade, showing a trend of decreasing with the increase of rocky desertification degree.

Table 2. Adaptability differences of rocky desertification environment in different grades

\begin{tabular}{c|c|c|c}
\hline & $\begin{array}{c}\text { Light-moderate rocky } \\
\text { desertification } \\
\text { environment }\end{array}$ & $\begin{array}{c}\text { Potential-light rocky } \\
\text { desertification environment }\end{array}$ & $\begin{array}{c}\text { Moderate-intensity rocky } \\
\text { desertification environment }\end{array}$ \\
\hline $\begin{array}{c}\text { Miscanthus floridulus, } \\
\text { Setaria viridis, Pteris } \\
\text { species }\end{array}$ & $\begin{array}{c}\text { Saccharum arundinaceum, } \\
\text { Robinia pseudoacacia, } \\
\text { parviflora, Viburnum } \\
\text { propinquum, Itea } \\
\text { yunnanensis and other } \\
\text { species }\end{array}$ & $\begin{array}{c}\text { Ligustrum lucidum, and } \\
\text { Artemisia dubia are dominant or } \\
\text { established species of plant } \\
\text { communities }\end{array}$ & $\begin{array}{c}\text { Broxtail, Arthraxon hispidus, } \\
\text { Broussonetia papyrifera, } \\
\text { Lonicera japonica, } \\
\text { Ampelocalamus calcareous, etc }\end{array}$ \\
\hline
\end{tabular}

Table 3. Plant diversity indices in different grades of rocky desertification environment

\begin{tabular}{c|c|c|c|c}
\hline $\begin{array}{c}\text { Degrees of rocky } \\
\text { desertification }\end{array}$ & Evenness index & Richness index & $\begin{array}{c}\text { Shannon-Wiener } \\
\text { index }\end{array}$ & $\begin{array}{c}\text { Dominance } \\
\text { index }\end{array}$ \\
\hline Nil & $12.65 \pm 0.35 \mathrm{a}$ & $12.65 \pm 0.63 \mathrm{a}$ & $2.26 \pm 0.63 \mathrm{ab}$ & $0.28 \pm 0.09 \mathrm{~b}$ \\
Potential & $1.33 \pm 0.26 \mathrm{~b}$ & $6.53 \pm 0.35 \mathrm{~b}$ & $1.82 \pm 0.52 \mathrm{a}$ & $0.58 \pm 0.09 \mathrm{~b}$ \\
Low & $0.38 \pm 0.12 \mathrm{c}$ & $12.17 \pm 0.28 \mathrm{a}$ & $2.48 \pm 0.67 \mathrm{ab}$ & $0.32 \pm 0.08 \mathrm{~b}$ \\
Middle & $0.42 \pm 0.11 \mathrm{c}$ & $10.75 \pm 1.02 \mathrm{ab}$ & $2.91 \pm 0.57 \mathrm{bc}$ & $0.17 \pm 0.05 \mathrm{~b}$ \\
High & $0.75 \pm 0.13 \mathrm{c}$ & $9.26 \pm 0.67 \mathrm{ab}$ & $3.28 \pm 0.74 \mathrm{c}$ & $0.13 \pm 0.05 \mathrm{~b}$ \\
\hline
\end{tabular}

The numerator value is the layer A of farmland soil and the denominator is the layer B of farmland soil

\section{Correlation between plant diversity and soil physicochemical properties}

The results of the correlation between plant diversity and soil physicochemical properties shows that (Table 4), there is a significant correlation between plant diversity in rocky desertification and soil physicochemical properties: (1) the richness index is negatively correlated with bulk density, total porosity, field water content, capillary water content, upper saturated permeability, organic matter, total nitrogen, total phosphorus and hydrolyzed nitrogen, and positively correlated with $\mathrm{pH}$ value, available potassium and soil respiration. (2) Diversity index is negatively correlated with bulk density, but positively correlated with total porosity, field water content, capillary water content, $\mathrm{pH}$ value, organic matter, total nitrogen and hydrolyzed nitrogen, and positively correlated with available phosphorus and available potassium. (3) The uniformity index had a significant negative correlation with $\mathrm{pH}$ and available phosphorus, a significant negative correlation with total phosphorus, a significant positive correlation with total potassium, and a significant positive correlation with soil respiration in farmland. (4) 
The dominance index has a significant negative correlation with capillary porosity, and has a significant negative correlation with field water holding capacity, $\mathrm{pH}$ value, total nitrogen, total phosphorus and hydrolyzed nitrogen, and a significant positive correlation with the lower layer saturated permeability. There is a significant positive correlation with non-capillary porosity. It can be seen that changes in soil physicochemical properties of farmland in rocky desertification environment can easily affect the characteristics of plant diversity.

Table 4. Correlation between physical and chemical factors of rocky desertification and plant diversity

\begin{tabular}{c|c|c|c|c}
\hline Soil physical-chemical factors & $\begin{array}{c}\text { Richness } \\
\text { index }\end{array}$ & $\begin{array}{c}\text { Shannon-Wiener } \\
\text { index }\end{array}$ & $\begin{array}{c}\text { Evenness } \\
\text { index }\end{array}$ & $\begin{array}{c}\text { Dominance } \\
\text { index }\end{array}$ \\
\hline Bulk density $/\left(\mathrm{g} / \mathrm{cm}^{3}\right)$ & $-0.454^{* *}$ & $-0.408^{* *}$ & -0.013 & 0.174 \\
Capillary porosity/\% & 0.157 & 0.211 & -0.114 & $-0.335^{* *}$ \\
Non-capillary porosity/\% & 0.136 & 0.043 & 0.134 & $0.251^{*}$ \\
Total porosity/\% & $0.346^{* *}$ & $0.311^{* *}$ & 0.009 & -0.104 \\
Natural moisture content/\% & 0.179 & -0.014 & 0.152 & 0.052 \\
Field moisture content/\% & $0.518^{* *}$ & $0.516^{* *}$ & 0.17 & $-0.266^{* *}$ \\
Capillary moisture content/\% & $0.499^{* *}$ & $0.532^{* *}$ & -0.001 & -0.193 \\
Upper strata saturated permeability/(mm/min) & $0.365^{* *}$ & 0.241 & -0.063 & 0.17 \\
Lower strata saturated permeability/(mm/min) & 0.223 & -0.008 & -0.171 & $0.359^{* *}$ \\
pH value & $0.248^{*}$ & $0.398^{* *}$ & $-0.541^{* *}$ & $-0.284^{*}$ \\
Organic matter content/(mg/kg) & $0.635^{* *}$ & $0.349^{* *}$ & 0.143 & -0.092 \\
Total nitrogen content $/(\mathrm{g} / \mathrm{kg})$ & $0.719^{* *}$ & $0.572^{* *}$ & -0.088 & $-0.262^{*}$ \\
Total phosphorus content $/(\mathrm{g} / \mathrm{kg})$ & $0.306^{* *}$ & 0.213 & $-0.34^{*}$ & $-0.24^{*}$ \\
Total potassium content $/(\mathrm{g} / \mathrm{kg})$ & -0.018 & -0.199 & $0.396^{* *}$ & 0.175 \\
Hydrolysis nitrogen content $/(\mathrm{mg} / \mathrm{g})$ & $0.759^{* *}$ & $0.385^{* *}$ & -0.011 & $-0.226^{*}$ \\
Available phosphorus content $/(\mathrm{mg} / \mathrm{kg})$ & 0.092 & $0.247^{*}$ & $-0.309^{* *}$ & -0.085 \\
Available potassium content/(mg/kg) & $0.26^{*}$ & $0.253^{*}$ & 0.127 & 0.015 \\
Soil respiration/ & $0.405^{*}$ & -0.107 & $0.327^{*}$ & -0.029 \\
\hline
\end{tabular}

(In the table, * means general correlation, ** means significant correlation.)

The degree of dimensionality of plant diversity index and soil main physical index of a national nature reserve is obvious (factor extraction value $>1.0$ ), and the cumulative variance contribution rate of trees, shrubs, herbaceous plant diversity factors and other factors in soil layer $\mathrm{A}$ and layer $\mathrm{B}$ is $90.00 \%, 91.49 \%$. The cumulative variance contribution of the water holding capacity factor dominated by soil density, maximum water holding capacity and field water holding capacity, and the porosity factor dominated by non-capillary porosity, capillary porosity and total porosity in layer A and $\mathrm{B}$ is $95.75 \%, 94.63 \%$. The main chemical index value of the soil has a large dimensionality difference (factor extraction value $>0.5$ ). The common factor includes the fertility factor dominated by organic mass, total nitrogen and hydrolyzed nitrogen, and the amount of cation exchange, exchangeable salt base and the total phosphorusdominated nutrient factor, the nitrogen factor dominated by total nitrogen, exchangeable salt base and $\mathrm{pH}$, and the layer $\mathrm{A}$ also has a phosphorus factor dominated by total phosphorus, available phosphorus and cation exchange, potassium factor dominated by 
potassium, organic matter and hydrolyzed nitrogen, and phosphorus factor in soil layer $\mathrm{B}$ dominated by effective phosphorus and exchangeable salt base, potassium factor dominated by total potassium, available potassium and cation exchange. The cumulative variance of soil fertility, nutrient, nitrogen, phosphorus and potassium factors in layer A and $\mathrm{B}$ is $83.06 \%$ and $87.60 \%$.

\section{Changes in main physicochemical indicators of farmland soil in a national nature reserve}

There are no significant differences in the main physical indices of farmland soils between different forest types (Table 5). Farmland soil density, capillary porosity and total porosity, as well as maximum water holding capacity and field water holding capacity shows a trend of layer A > layer B. The non-capillary porosity values in the type I, III and V show the trend of layer A > layer B, in line with the general law; analysis of type II and IV showing the trend of layer B > layer A is due to the fact that there are many fractures in the parent rock at the sampling point part of the farmland soil in $50 \%$ of the plot, and the underground erosion of the layer Bin farmland causes the non-capillary porosity to be higher, and the other $50 \%$ of the sample is still in the trend of layer A > layer B. Type IV forest land has high rock exposure rate, low farmland soil density value, non-capillary porosity and total porosity, and maximum water holding capacity and field water holding capacity; Type III forest rock has low bare exposure rate, thin soil layer, small farmland soil density value, non-capillary porosity and total porosity, and maximum water holding capacity and field water holding capacity. The rock exposure rate and soil physicochemical indicators of type I and II forests are middle and the change is large.

Table 5. Change of main physical indexes of soil of different karst forest types

\begin{tabular}{|c|c|c|c|c|c|c|c|c|c|}
\hline \multirow[b]{2}{*}{ Types } & \multicolumn{4}{|c|}{ Profile property } & \multicolumn{3}{|c|}{ Porosity } & \multicolumn{2}{|c|}{ Water holding capacity } \\
\hline & Slope/( $\left(^{\circ}\right)$ & $\begin{array}{c}\text { Bare rock } \\
\text { rate/\% }\end{array}$ & $\mathrm{PD} / \mathrm{cm}$ & $\begin{array}{l}\text { Density/ } \\
\left(\mathrm{g} / \mathrm{cm}^{3}\right)\end{array}$ & $\begin{array}{c}\text { Capillary } \\
\text { porosity/\% }\end{array}$ & $\begin{array}{c}\text { Non- } \\
\text { capillary } \\
\text { porosity/\% }\end{array}$ & $\begin{array}{c}\text { Total } \\
\text { porosity } / \%\end{array}$ & $\begin{array}{c}\text { Field } \\
\text { capacity/ } \\
\left(\times 10^{2} g / k g\right)\end{array}$ & $\begin{array}{c}\text { Maximum } \\
\text { water } \\
\text { capacity/ } \\
\left(\times 10^{2} g / \mathrm{kg}\right)\end{array}$ \\
\hline Study area I & 13.66 & 34.4 & 17.8 & $1.138 / 1.212$ & $45.95 / 42.32$ & $7.50 / 4.84$ & $53.45 / 47.16$ & $4.172 / 3.520$ & $4.927 / 3.989$ \\
\hline Study area II & 11.22 & 25.96 & 11.48 & $1.281 / 1.331$ & $41.80 / 36.70$ & $6.0 / 7.85$ & $47.80 / 44.55$ & $3.138 / 2.639$ & $3.740 / 3.347$ \\
\hline Study area III & 15.67 & 15.67 & 11.33 & $1.086 / 1.360$ & $48.70 / 40.00$ & $6.57 / 5.83$ & $55.27 / 45.83$ & $4.353 / 2.921$ & $5.107 / 3.420$ \\
\hline Study area IV & 16.25 & 69.5 & 12.25 & $0.958 / 1.203$ & $56.30 / 44.78$ & $3.08 / 4.50$ & $59.38 / 49.28$ & $5.743 / 3.810$ & $6.384 / 4.106$ \\
\hline
\end{tabular}

In the table, the numerator value is the layer $\mathrm{A}$ of farmland soil and the denominator is the layer B of farmland soil.

There are no significant differences in the main chemical indices of farmland soils between different forest types (Tables 6 and 7). The $\mathrm{pH}$ value and total potassium content of farmland soil shows the trend of layer A < layer B; the trend of soil organic matter quality, cation exchange amount, exchangeable salt base amount, total nitrogen amount, total phosphorus amount, hydrolyzed nitrogen amount, available phosphorus amount and available potassium is layer $\mathrm{A}>$ layer $\mathrm{B}$. The change trend of total phosphorus and total potassium in layer A and B layer of farmland soil is different from other types, among which $50 \%$ of farmland soil total phosphorus and $75 \%$ of farmland soil total potassium change are contrary to the general law, which is related to the heterogeneity of farmland soil sample sites and farmland soil heterogeneity and the 
underground erosion formed by the parent rock fissures. The soil fertility and nutrient index of type IV farmland are higher, the soil fertility and nutrient index of type III farmland are lower, and the soil fertility and nutrient index of type I, II and IV are middle, with larger variation.

Table 6. Change of main soil fertility indexes of different karst forest types

\begin{tabular}{c|c|c|c|c}
\hline Types & $\mathbf{p H}$ & $\begin{array}{c}\text { Organic } \\
\text { mass } /(\times 10 \mathrm{~g} / \mathrm{kg})\end{array}$ & $\begin{array}{c}\text { Cation exchange } \\
\text { capacity } /\left(\times 10 \mathrm{cmol}^{*} / \mathrm{kg}\right)\end{array}$ & $\begin{array}{c}\text { Exchangeable base } \\
\text { amount } /\left(\times 10 \mathrm{cmol}^{*} / \mathrm{kg}\right)\end{array}$ \\
\hline Study area I & $6.55 / 6.62$ & $6.32 / 3.34$ & $3.89 / 2.44$ & $1.08 / 1.07$ \\
Study area II & $6.38 / 6.41$ & $2.49 / 1.89$ & $2.22 / 1.30$ & $0.86 / 0.86$ \\
Study area III & $6.05 / 6.22$ & $6.14 / 2.16$ & $4.24 / 2.82$ & $1.50 / 1.18$ \\
Study area IV & $6.46 / 6.63$ & $5.95 / 3.40$ & $6.30 / 4.63$ & $3.34 / 3.08$ \\
\hline
\end{tabular}

The numerator value is the layer A of farmland soil and the denominator is the layer B of farmland soil.

Table 7. Changes of main nutrient indexes of soil of different karst forest types

\begin{tabular}{c|c|c|c|c|c|c}
\hline Types & $\begin{array}{c}\text { Total nitrogen } \\
\text { content } /(\mathrm{g} / \mathbf{k g})\end{array}$ & $\begin{array}{c}\text { Total } \\
\text { phosphorus } \\
\text { content/(g/kg) }\end{array}$ & $\begin{array}{c}\text { Total potassium } \\
\text { content/ } \\
(\times 10 \mathrm{~g} / \mathrm{kg})\end{array}$ & $\begin{array}{c}\text { Hydrolysis nitrogen } \\
\text { content/ } \\
\left(\times 10^{2} \mathrm{mg} / \mathrm{kg}\right)\end{array}$ & $\begin{array}{c}\text { Available } \\
\text { phosphorus } \\
\text { content } /(\mathbf{m g} / \mathbf{k})\end{array}$ & $\begin{array}{c}\text { Available potassium } \\
\text { content/ }\left(\times 10^{2} \mathrm{mg} / \mathrm{kg}\right)\end{array}$ \\
\hline Study area I & $2.63 / 2.52$ & $0.30 / 0.29$ & $3.99 / 4.02$ & $2.65 / 1.64$ & $2.76 / 1.85$ & $1.68 / 0.91$ \\
Study area II & $2.25 / 1.28$ & $0.29 / 0.27$ & $3.75 / 3.97$ & $1.59 / 1.21$ & $5.02 / 3.51$ & $1.22 / 1.00$ \\
Study area III & $4.87 / 0.98$ & $0.22 / 0.13$ & $4.15 / 4.38$ & $2.97 / 0.90$ & $1.65 / 1.46$ & $2.54 / 1.32$ \\
Study area IV & $4.92 / 2.02$ & $0.35 / 0.40$ & $4.53 / 4.38$ & $3.10 / 1.51$ & $2.13 / 1.56$ & $2.49 / 1.51$ \\
\hline
\end{tabular}

The numerator value is the layer $\mathrm{A}$ of farmland soil and the denominator is the layer B of farmland soil

The correlation between different stratified plant diversity factors and soil physicochemical factors in different soil layers is different, which is consistent with the general characteristics of growth and development during the natural restoration process of trees, shrubs and herbaceous plants. According to the proportional relationship between relevant important factors and quantity in Table 7, the more nitrogen, phosphorus and potassium content in the study area, the richer plant diversity in the study area. The contents of nitrogen, phosphorus, potassium and other important factors in each class landform forest can fully explain the following results: The relevant significant factor-to-quantity ratios shows the trend of arbor layer $(36.38 \%)>$ shrub layer $(27.27 \%)>$ herb layer $(18.9 \%)$, layer A in farmland soil $(45.45 \%)<$ layer B $(54.55 \%)$. The plant diversity factor of arbor layer plays a leading role.

\section{Correlation between plant diversity index of arbor layer and soil physicochemical indicators in a national nature reserve}

The correlation coefficient between the plant diversity index of forest arbor layer and the soil physicochemical index of farmland shows a trend of quadratic polynomial (QC) $\geq$ linear (SL). The significant indicators are $46.09 \%$ and $39.84 \%$, respectively, showing the trend of the Layer A $(\mathrm{QC}=21.88 \%, \mathrm{SL}=18.75 \%$, the same below $)<$ layer B $(24.22 \%, 21.09 \%)$, Pielou index $(14.06 \%, 13.28 \%)>$ Simpson index $(12.50 \%$, $10.94 \%)>$ Shannon-Wiener index $(10.16 \%, 8.59 \%)>$ Margalef index $(9.38 \%, 7.03 \%)$ as shown in Table 8 . Among the related significant quantitative rate, the soil physical index of farmland is quadratic polynomial $(66.67 \%)>$ linear $(62.50 \%)$, layer A > layer 
$\mathrm{B}$, and the soil fertility index of farmland is quadratic polynomial $(37.50 \%)>$ linear (31.25\%), layer $\mathrm{A}>$ layer $\mathrm{B}$, farmland soil nutrient index is quadratic polynomial $(31.25 \%)>$ linear $(22.92 \%)$, layer A < layer B in farmland soil. Significant correlations between plant diversity index in arbor layer and soil physical, fertility and nutrient indices are found. The logarithmic quantitative rate varies with species of diversity index, soil layers and types of physical and chemical indices, but the trend does not change with model types.

Table 8. Correlation between plant diversity index and soil physical and chemical indexes in karst forest trees

\begin{tabular}{|c|c|c|c|c|c|c|c|c|c|}
\hline & \multirow{2}{*}{ Indicators } & \multirow[b]{2}{*}{ A horizon } & \multirow[b]{2}{*}{ B horizon } & \multicolumn{2}{|c|}{ Simpson index } & \multicolumn{2}{|c|}{ Shannon-Wiener index } & \multicolumn{2}{|c|}{ Pielou index } \\
\hline & & & & A horizon & B horizon & A horizon & B horizon & A horizon & B horizon \\
\hline \multirow{12}{*}{ 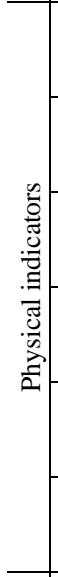 } & \multirow{2}{*}{ Density } & $-0.512^{* *}$ & $-0.405^{*}$ & $-0.526^{* *}$ & $-0.436^{*}$ & $-0.553^{* *}$ & $-0.405^{* *}$ & $-0.568^{* *}$ & $-0.413^{*}$ \\
\hline & & $-0.514^{* *}$ & $-0.534^{* *}$ & $-0.569^{* *}$ & $-0.512^{* *}$ & $-0.553^{* *}$ & $-0.506^{* *}$ & $-0.574^{* *}$ & $-0.484^{* *}$ \\
\hline & \multirow{2}{*}{ Capillary porosity } & -0.148 & 0.29 & 0.191 & $0.431^{*}$ & -0.058 & 0.325 & 0.17 & $0.387^{*}$ \\
\hline & & -0.243 & 0.292 & 0.246 & $0.439^{*}$ & -0.264 & 0.326 & 0.229 & $0.387^{*}$ \\
\hline & \multirow{2}{*}{ Non-capillary porosity } & $0.433^{* *}$ & 0.049 & 0.245 & -0.075 & $0.402^{*}$ & 0.029 & 0.301 & -0.003 \\
\hline & & $0.476^{* *}$ & 0.352 & $0.379^{*}$ & -0.328 & $0.433^{* *}$ & 0.088 & 0.315 & -0.046 \\
\hline & \multirow{2}{*}{ Total porosity } & 0.252 & 0.286 & $0.421^{* *}$ & 0.328 & 0.314 & 0.303 & $0.452^{* *}$ & 0.336 \\
\hline & & 0.252 & 0.351 & $0.436^{* *}$ & 0.354 & 0.334 & 0.311 & $0.457^{* *}$ & 0.337 \\
\hline & \multirow{2}{*}{ Field capacity } & $0.351^{*}$ & $0.4^{*}$ & $0.465^{* *}$ & $0.453^{*}$ & $0.391^{*}$ & $0.389^{*}$ & $0.462^{* *}$ & $0.426^{*}$ \\
\hline & & $0.359^{*}$ & $0.447^{*}$ & $0.478^{* *}$ & $0.474^{*}$ & $0.396^{*}$ & $0.455^{*}$ & $0.47^{* *}$ & $0.435^{*}$ \\
\hline & \multirow{2}{*}{$\begin{array}{l}\text { Maximum water } \\
\text { capacity }\end{array}$} & $0.439^{* *}$ & $0.411^{*}$ & $0.419^{* *}$ & $0.415^{*}$ & $0.449^{* *}$ & $0.392^{*}$ & $0.445^{* *}$ & $0.402^{*}$ \\
\hline & & $0.443^{* *}$ & $0.49^{* *}$ & $0.456^{* *}$ & $0.474^{*}$ & $0.453^{* *}$ & $0.465^{*}$ & $0.45^{* *}$ & $0.439^{* *}$ \\
\hline \multirow{8}{*}{ 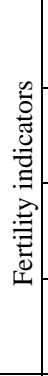 } & \multirow{2}{*}{$\mathrm{pH}$} & 0.186 & 0.08 & 0.186 & 0.07 & 0.231 & 0.127 & 0.228 & 0.159 \\
\hline & & 0.195 & 0.094 & 0.266 & 0.244 & 0.305 & 0.26 & 0.313 & 0.28 \\
\hline & \multirow{2}{*}{ Organic mass } & $0.348^{*}$ & 0.272 & $0.474^{* *}$ & $0.424^{*}$ & $0.338^{*}$ & 0.302 & $0.452^{* *}$ & $0.381^{*}$ \\
\hline & & $0.368^{*}$ & 0.277 & $0.476^{* *}$ & $0.443^{*}$ & $0.381^{*}$ & 0.306 & $0.453^{* *}$ & $0.382^{*}$ \\
\hline & \multirow{2}{*}{$\begin{array}{l}\text { Cation exchange } \\
\text { capacity }\end{array}$} & 0.182 & 0.362 & 0.313 & 0.365 & 0.277 & $0.416^{*}$ & 0.393 & 0.43 \\
\hline & & 0.273 & $0.382^{*}$ & 0.313 & 0.376 & $0.359^{*}$ & $0.419^{*}$ & $0.41^{*}$ & $0.435^{*}$ \\
\hline & \multirow{2}{*}{$\begin{array}{c}\text { Exchangeable base } \\
\text { amount }\end{array}$} & 0.105 & 0.122 & 0.272 & 0.178 & 0.182 & 0.174 & $0.361^{*}$ & 0.279 \\
\hline & & 0.12 & 0.13 & 0.283 & 0.181 & 0.215 & 0.183 & $0.387^{*}$ & 0.279 \\
\hline \multirow{12}{*}{ 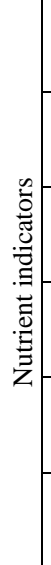 } & \multirow{2}{*}{ Total nitrogen content } & 0.112 & 0.207 & 0.29 & $0.44^{*}$ & 0.184 & 0.29 & $0.351^{*}$ & $0.417^{*}$ \\
\hline & & 0.197 & 0.27 & 0.295 & $0.451^{*}$ & 0.307 & 0.302 & $0.378^{*}$ & $0.421^{*}$ \\
\hline & \multirow{2}{*}{$\begin{array}{l}\text { Total phosphorus } \\
\text { content }\end{array}$} & -0.221 & 0.098 & -0.095 & 0.232 & -0.164 & 0.16 & 0.022 & 0.299 \\
\hline & & -0.238 & 0.201 & -0.101 & 0.313 & -0.215 & 0.197 & 0.027 & 0.333 \\
\hline & \multirow{2}{*}{$\begin{array}{l}\text { Total potassium } \\
\text { content }\end{array}$} & 0.049 & 0.149 & 0.193 & 0.293 & 0.158 & 0.235 & 0.259 & 0.36 \\
\hline & & 0.249 & $0.453^{*}$ & 0.302 & $0.43^{*}$ & 0.192 & 0.321 & 0.305 & $0.399^{*}$ \\
\hline & \multirow{2}{*}{$\begin{array}{l}\text { Hydrolysis nitrogen } \\
\text { content }\end{array}$} & 0.23 & 0.369 & $0.337^{*}$ & $0.456^{*}$ & 0.23 & $0.384^{*}$ & 0.268 & $0.434^{*}$ \\
\hline & & 0.283 & 0.378 & $0.363^{*}$ & $0.538^{* *}$ & 0.313 & $0.387^{*}$ & 0.287 & $0.436^{*}$ \\
\hline & \multirow{2}{*}{$\begin{array}{l}\text { Available phosphorus } \\
\text { content }\end{array}$} & -0.094 & -0.008 & -0.202 & -0.099 & -0.142 & -0.074 & -0.156 & -0.114 \\
\hline & & -0.19 & -0.203 & -0.205 & -0.112 & -0.171 & -0.103 & -0.159 & -0.176 \\
\hline & \multirow{2}{*}{$\begin{array}{c}\text { Available potassium } \\
\text { content }\end{array}$} & 0.145 & $0.381^{*}$ & 0.227 & $0.494^{* *}$ & 0.16 & $0.49^{* *}$ & 0.201 & $0.609^{* *}$ \\
\hline & & $0.365^{*}$ & $0.569^{* *}$ & 0.242 & $0.505^{* *}$ & 0.3 & $0.536^{* *}$ & 0.309 & $0.635^{* *}$ \\
\hline
\end{tabular}

(In the table, * means general correlation, ** means significant correlation.) 
According to Table 8, based on the difference between the quadratic polynomial and the linear correlation between the plant diversity index and the farmland soil physicochemical indicators, it can be divided into three types. (1) The correlation is not significant, including farmland soil $\mathrm{pH}$, total phosphorus and available phosphorus, the indicator rate is $53.91 \%$, which is farmland soil layer A $(28.13 \%)>\mathrm{B}$ layer $(25.75 \%)$ /Margale index $(15.63 \%)>$ Shannon-Wiener Index $(14.84 \%)>$ Simpson Index $(12.50 \%)>$ Pielou Index (10.94\%). (2) Only the significant type of curve correlation, including total potassium of layer B in farmland soil, etc., the indicator pair rate is $5.47 \%$, showing the trend of layer A in farmland soil $(2.34 \%)<$ layer B $(3.13 \%)$, Pielou index $(0.78 \%)<$ Simpson index $(1.56 \%)=$ Shannon-Wiener index $(1.56 \%)<$ Margalef index (2.34\%).(3) Significant type of correlation. Both linear and quadratic polynomial correlations are significant, including farmland soil density, field water holding capacity and maximum water holding capacity, organic quality of layer A in farmland soil and available potassium of B layer. The indicator rate is $40.63 \%$, which shows the trend of layer A $(19.53 \%)<$ layer B $(21.09 \%)$ and Margalef index $(7.03 \%)<$ Shannon-Wiener index $(8.59 \%)<$ Simpson index $(10.94 \%)<$ Pielou index $(13.28 \%)$.

\section{Discussion}

\section{Discussion on the plant diversity of rocky desertification environment and the physicochemical properties of farmland soil}

Compared with the experimental results of traditional methods, the results of this paper show that there is no obvious coupling relationship between the richness index, diversity index and dominance index of rocky desertification plant community at different levels and the succession of rocky desertification. This should be the result of human interference. After the natural state is superimposed by human activities, the natural law of vegetation restoration is disturbed. The change of evenness index has remarkable coupling relation with the succession of rocky desertification degree. With the increase of rocky desertification level, the evenness index showed a trend of gradual decrease, indicating that the evenness index of plant diversity should be an important basis for plant community evaluation in rocky desertification areas. The deterioration of rocky desertification environment leads to the decrease of plant diversity. The evolution of farmland soil properties under rocky desertification is not a process of degradation with the increase of rocky desertification level, but a gradual process of degradation and then improvement. The reason is the result of soil erosion of rocky desertification and soil nutrient accumulation of bare rocky desertification. With the increase of rocky desertification, the accumulation effect of bare rock increased gradually, and the input of soil nutrients in farmland increased. With the increase of rocky desertification, soil loss can be reduced, soil erosion is weakened, and soil nutrient loss of corresponding farmland is weakened. The combination of these processes leads to the gradual improvement of degraded farmland soils. The evolution process of the physical and chemical properties of farmland soil in rocky desertification is as follows: when forest vegetation is destroyed in rocky desertification environment, the loss of soil nutrients in farmland increases with the increase of soil and water loss, the input of organic matter in garbage decreases, the bulk density of farmland soil increases, nitrogen and water capacity decrease, and farmland soil degradation. The accumulation of nutrients and karst products in the atmosphere increased, and the input of organic matter and nitrogen in farmland soil increased. At the same time, with the increase of rocky desertification 
degree, soil loss can be reduced, soil erosion weakened, soil nutrient loss in farmland reduced, soil nutrient and farmland physical properties gradually improved.

\section{Discussion on plant diversity and soil physicochemical properties of a national nature reserve}

In this paper, the distribution of the same type of cross-adjacent functional area exists in the forest type by the important value of the arbor layer species. Because the important value only reflects the dominant degree of the species in the community, does not reflect its growth and development stage, and there are different functional areas, the type of division can still be interpreted. The application of other indicators may better express the types of forests in different functional areas, but the main indicators and related trends of vegetation-farm soil systems will not change. In this paper, the significant differences in soil organic matter, total nitrogen, hydrolyzed nitrogen, available phosphorus and available potassium are different. The plant diversity index is similar to that of farmland soil. The correlation coefficient of the index value decreases or increases with the increase of the soil layer thickness. The correlation significant index shows the trend of the layer $\mathrm{A}<$ layer $\mathrm{B}$, which is different from the non-natural secondary forest and similar to other natural secondary forests. It indicates that the correlation between forest plant diversity index and soil physicochemical index values is specific between soil layers.

\section{Restoration and reconstruction of degraded ecosystems in rocky desertification area}

The rocky desertification ecosystem has a simple vegetation community and a very low abundance. The rocky desertification environment has significant stress on its plant distribution. The plants in rocky desertification environment must have the characteristics of stone nature, calcium tolerance and drought tolerance, but also have a well-developed and strong root system, which has important guiding significance in the restoration and reconstruction of degraded ecosystems in rocky desertification area. The plants of Compositae, Rosaceae, Gramineae, Lonicerae, Euphorbiaceae and other plants are mostly distributed in rocky desertification environment, indicating that these groups have strong adaptability to rocky desertification environment, which provides an important reference for the application of vegetation restoration technology and the selection of pioneer species. Among them, the Rosaceae plants have more genus distribution in the potential and mild rocky desertification environment, while the number of species distributed in the intensity rocky desertification environment decreases significantly, indicating that the adaptability of adaptable species in different grades of rocky desertification environment are is significantly different. Therefore, in the process of controlling desertification and selecting species by rocky desertification, it is necessary to screen not only the species that adapt to the rocky desertification environment, but also the adaptive pioneer species for different grades of rocky desertification environment, so that it can achieve the expected goal of vegetation restoration in rocky desertification control. The degradation of fragile ecosystems is driven by strong human disturbances, with vegetation reduction as the cause, degradation of land productivity as the essence, and a composite process marked by similar desertification landscapes. The diversity and structural index of vegetation community in rocky desertification environment are low, and the stability is poor. Therefore, the vegetation with strong primitiveness and without disturbance should keep 
the status quo and develop naturally. The disturbed rocky desertification ecosystem should supplement the post-successive propagules, paying special attention to the introduction of some top or sub-top species; secondary forest areas should be properly trimmed to maintain reasonable density, which is conducive to sexual reproduction and renewal chain as soon as possible. Recovery and rapid growth of forests promote the uniform distribution of species composition, rationalize the diversity, and achieve rapid restoration and formation of plant communities.

\section{Conclusions}

In this paper, a rocky desertification area and a national nature reserve are used as research objects to analyze the correlation effects of plant species diversity on the physicochemical properties of soil microbes. Three typical rock desertification areas and one national level nature protection are selected as the sample area. Through the collection and analysis of the physicochemical properties of the farmland soil samples in the rock desertification area, the results of the physical properties of the soils, such as the bulk density, field water capacity, natural water content, capillary water capacity, total porosity, capillary porosity, and non-capillary porosity, and the determination results of the chemical properties of the farmland soils such as $\mathrm{pH}$, organic matter, total nitrogen, total phosphorus, total potassium, available phosphorus and available potassium are obtained. Based on this, the correlation between plant diversity and the physicochemical properties of farmland soil in the rocky desertification environment and the correlation between plant diversity and soil microbes in a national nature reserve are studied. After measuring the physicochemical indicators of farmland soil, the plant diversity index is calculated to study the physicochemical properties of farmland soils of different forest types. The change of index value is used to study the correlation between plant diversity of national nature reserve and soil microbes in farmland.

\section{REFERENCES}

[1] Baćmaga, M., Wyszkowska, J., Kucharski, J. (2016): The effect of the Falcon 460 EC fungicide on soil microbial communities, enzyme activities and plant growth. Ecotoxicology 25(8): 1-13.

[2] Baleshta, K. E., Simard, S. W., Roach, W. J. (2015): Effects of thinning paper birch on conifer productivity and understory plant diversity. - Scandinavian Journal of Forest Research 30(8): 699-709.

[3] Bazerman, C., Applebee, A. N., Berninger, V. W., Brandt, D., Graham, S., Matsuda, P. K., Murphy, S., Rowe, D. W., Schleppegrell, M. (2017): Taking the long view on writing development. - Research in the Teaching of English 51(3): 351-360.

[4] Camara, E. M., Caramaschi, E. P., Di Dario, F., Petry, A. C. (2018): Short-term changes in two tropical coastal lagoons: effects of sandbar openings on fish assemblages. Journal of Coastal Research 34(1): 90-105.

[5] He, Q. H., Tang, X. J., Tang, X. J. (2016): Research on soil parameter identification of excavator digging. - Computer Simulation 33(2): 361-366.

[6] Jiang, S. C., Ge, S. B., Wu, X., Yang, Y. M., Chen, J. T., Peng, W. X. (2017): Treating nbutane by activated carbon and metal oxides. - Toxicological and Environmental Chemistry 99(5-6): 753-759. 
[7] Kolton, M., Graber, E. R., Tsehansky, L. (2016): Biochar-stimulated plant performance is strongly linked to microbial diversity and metabolic potential in the rhizosphere. - New Phytologist 213(3): 1393-1404.

[8] Li, J. H., Zhang, H., Li, W. J. (2015): Plant-soil feedbacks in a sub-alpine meadow ecosystem with high plant diversity on the Qinghai-Tibetan Plateau. - Plant Ecology 216(12): 1659-1674.

[9] Li, P., Zhang, J., Xie, H. (2015): Effects of Misgurnus anguillicaudatus and Cipangopaludina cathayensis on pollutant removal and microbial community in constructed wetlands. - Water 7(5): 2422-2434.

[10] Lloret, F., Mattana, S., Curiel, Y. J. (2015): Climate-induced die-off affects plant-soilmicrobe ecological relationship and functioning. - FEMS Microbiology Ecology 91(2): $1-12$.

[11] Ma, M., Baskin, C. C., Yu, K. (2017): Wetland drying indirectly influences plant community and seed bank diversity through soil pH. - Ecological Indicators 80(80): 186195.

[12] Markowicz, A., Woźniak, G., Borymski, S. (2015): Links in the functional diversity between soil microbes and plant communities during natural succession in coal mine spoil heaps. - Ecological Research 30(6): 1005-1014.

[13] Mellado-Vázquez, P. G., Lange, M., Bachmann, D. (2016): Plant diversity generates enhanced soil microbial access to recently photosynthesized carbon in the rhizosphere.Soil Biology and Biochemistry 94: 122-132.

[14] Nyemb, J. N., Magnibou, L. M., Talla, E., Tchinda, A. T., Tchuenguem, R. T., Henoumont, C., Laurent, S., Mbafor, J. T. (2017): Lipids constituents from Gardenia aqualla Stapf and Hutch. - Open Chemistry. 16(1): 371-376.

[15] Økland, T., Nordbakken, J. F., Lange, H. (2016): Short-term effects of whole-tree harvesting on understory plant species diversity and cover in two Norway spruce sites in southern Norway. - Scandinavian Journal of Forest Research 31(8): 766-776.

[16] Shen, Y., Zhao, N., Xia, M., Du, X. (2017): A deep Q-learning network for ship stowage planning problem. - Polish Maritime Research 24(SI): 102-109.

[17] Steinauer, K., Tilman, D., Wragg, P. D. (2016): Plant diversity effects on soil microbial functions and enzymes are stronger than warming in a grassland experiment. - Ecology 96(1): 99-112.

[18] Sudhan, S. P. N., Ahmed, R. N., Kiyani, H., Mansoor, S. S. (2018): Ionic liquid 1-butyl3-methylimidazolium bromide: a green reaction media for the efficient synthesis of 3methyl-1,4-diphenyl-1,4,5,7-tetrahydro-pyrazolo [3,4-d]pyrimidine-6-ones/thiones using phthalimide-n-sulfonic acid as catalyst. - Journal of Saudi Chemical Society 22(3): 269278.

[19] Sun, J., Lu, J., Wang, W., Mu, Y., Zhao, J., Liu, C., Chen, L., Shi, L., Li, Q., Yang, T., Yan, L., Wan, Q., Wu, S., Liu, Y., Wang, G., Luo, Z., Tang, X., Chen, G., Huo, Y., Gao, Z., Su, Q., Ye, Z., Wang, Y., Qin, G., Deng, H., Yu, X., Shen, F., Chen, L., Zhao, L., Bi, Y., Xu, M., Xu, Y., Dai, M., Wang, T., Zhang, D., Lai, S., Ning, G. (2016): Prevalence of diabetes and cardiometabolic disorders in spouses of diabetic individuals. - American Journal of Epidemiology 184(5): 400-409.

[20] Sun, Y., Müllerschärer, H., Maron, J. L. (2015): Origin matters: diversity affects the performance of alien invasive species but not of native species. - American Naturalist 185(6): 725-736.

[21] Thakur, M. P., Milcu, A., Manning, P. (2015): Plant diversity drives soil microbial biomass carbon in grasslands irrespective of global environmental change factors. Global Change Biology 21(11): 4076-4085.

[22] Vej, J., Lamentowicz, Ł., Bjm, R. (2015): Plant functional diversity drives niche-size-structure of dominant microbial consumers along a poor to extremely rich fen gradient. - Journal of Ecology 102(5): 1150-1162. 
[23] Weidner, S., Koller, R., Latz, E. (2015): Bacterial diversity amplifies nutrient-based plant-soil feedbacks. - Functional Ecology 29(10): 1341-1349.

[24] Xiao, Q., Li, D., Guo, R., Zheng, L., An, X., Zeng, Z. (2018): In vivo and in vitro toxicities of diethyl phthalate to flounder fish Paralichthys olivaceus and its gill cell line (fg cells). - Journal of Environmental Biology 39(1): 73-81.

[25] Yan, X., Zhang, Y., Luo, X. (2016): Effects of uranium on soil microbial biomass carbon, enzymes, plant biomass and microbial diversity in yellow soils. - Radioprotection 51(3): 207-212.

[26] Zhalnina, K., Dias, R., Quadros, P. D. D. (2015): Soil pH determines microbial diversity and composition in the park grass experiment. - Microbial Ecology 69(2): 395-406.

[27] Zhang, X., Johnston, E. R., Barberán, A. (2017): Decreased plant productivity resulting from plant group removal experiment constrains soil microbial functional diversity. Global Change Biology 23(10): 4318-4332.

[28] Zhou, D., Zhang, H., Bai, Z. (2016): Exposure to soil, house dust and decaying plants increases gut microbial diversity and decreases serum immunoglobulin E levels in BALB/c mice. - Environmental Microbiology 18(5): 1326-1337. 